\title{
Systematics of the Jaguar catfish genus Liosomadoras Fowler, 1940 (Auchenipteridae: Siluriformes)
}

\author{
José L. O. Birindelli ${ }^{1}$ and Jansen Zuanon ${ }^{2}$
}

\begin{abstract}
Liosomadoras Fowler, 1940 includes two nominal species: L. oncinus, described from the rio Negro in Brazil, and L. morrowi described from the Peruvian Amazon. Both species are known from only few specimens deposited in fish collections, and information on these fishes is scarce. In order to rectify this situation, diagnoses of the genus and its species and an osteological description of $L$. oncinus are presented based on recently collected specimens. In addition, the taxonomy of the species of Liosomadoras is reviewed, and L. morrowi is confirmed as distinct from L. oncinus, and also distributed in the Brazilian Amazon. Liosomadoras is hypothesized as a relatively basal genus within Auchenipterinae, sister to all other species of the group, except Asterophysus batrachus and Tocantinsia piresi.
\end{abstract}

Liosomadoras Fowler, 1940 inclui duas espécies nominais: L. oncinus, descrita a partir de exemplares coletados no rio Negro no Brasil, e L. morrowi descrita da Amazônia Peruana. Ambas espécies são conhecidas a partir de poucos exemplares depositados em coleções, e informações sobre esses peixes são raras. Com o intuito de remediar esta situação, diagnoses do gênero e de suas espécies, e uma descrição osteológica de L. oncinus, são apresentadas com base em exemplares recentemente coletados. Além disso, a taxonomia das espécies de Liosomadoras é revista, e L. morrowi é confirmada como distinta de $L$. oncinus e também distribuída na Amazônia brasileira. Liosomadoras é considerado um gênero relativamente basal em Auchenipterinae, grupo irmão das demais espécies da subfamília, exceto Asterophysus batrachus e Tocantinsia piresi.

Key words: Auchenipterinae, Doradoidea, Phylogeny, Taxonomy.

\section{Introduction}

Jardine (in Schomburgk, 1841) described a species of catfish with a color pattern similar to that of the South American Jaguar Panthera onca Linnaeus, naming it Arius oncinus. Although the type specimen (or specimens) was not preserved, the species was described and illustrated in Schomburgk's (1841) publication in a detailed drawing (Fig. 1). The specimen was collected in the rio Padauiri, a tributary of the rio Negro in Brazil, on March 19, 1839 (Eigenmann \& Eigenmann, 1890; Mees, 1978). Arius oncinus was later mentioned in a footnote as belonging to Auchenipterus Valenciennes, by Günther (1864), and as a doubtful species of Centromochlus Kner by Eigenmann \& Eigenmann (1890) and Gosline (1945). Fowler (1940) described Liosomadoras morrowi from one specimen collected in the Peruvian Amazon, considering it as a member of the Doradidae. Additional specimens of both species were not deposited in scientific collections until M. R. Brittan collected one specimen at rio Xeruini in the Brazilian Amazon (rio Branco drainage) and purchased three others from the Cardinal Aquarium in Manaus. These specimens were illustrated in an article published in Tropical Fish Hobbyist (Brittan, 1976) and deposited at the California Academy of Sciences. Although identified as Centromochlus altae Fowler, 1945 by Brittan (1976), it was recognized by Mees (1978) as belonging to Arius oncinus. Based on the four specimens purchased and collected by Brittan, and on the holotype of Liosomadoras morrowi, Mees (1978) redescribed L. oncinus, recognizing $L$. morrowi as its junior synonym. Mees's (1978) decision was subsequently followed by other authors (Burgess, 1989; Eschmeyer, 1998; Akama \& Soares-Porto, 2007).

Burgess (1994) received from Adolf Schwartz (of International Fisheries, Inc.) three specimens of Liosomadoras that perfectly fit the description and color pattern of the holotype of L. morrowi. Burgess (1994) then upheld the validity of Fowler's Liosomadoras morrowi as a distinct species. Since then, some other aquarists published pictures of both species of Liosomadoras noting differences in color pattern (e.g., Finley, 1997). As expected, considering the

\footnotetext{
${ }^{1}$ Museu de Zoologia da Universidade de São Paulo, Caixa Postal 42494, 04218-970 São Paulo, SP, Brazil. josebirindelli@yahoo.com ${ }^{2}$ Instituto Nacional de Pesquisas da Amazônia, Caixa Postal 478, 69060-001 Manaus, AM, Brazil. jzuanon3@gmail.com
} 
nature of the publication where this information was available, the resurrection of $L$. morrowi was not promptly noticed by the scientific community (e.g., Eschmeyer, 1998; Akama \& Soares-Porto, 2007). Nevertheless, it was accepted more recently (Ferraris, 2003, 2007; Eschmeyer \& Fricke, 2012), even though specimens of $L$. morrowi apart from the holotype were still uncataloged in fish collections.

In recent years, several specimens of both Liosomadoras oncinus and L. morrowi were collected or obtained from the fish trade. Based on this new material, diagnoses of the genus and of its species, and a detailed osteological description of Liosomadoras oncinus, are presented. In addition, relevant morphological features present in Liosomadoras are discussed within a phylogenetic framework for the Auchenipteridae.

\section{Material and Methods}

Measurements and meristic follow Akama \& Ferraris (2003). Standard Length (SL) is expressed in $\mathrm{mm}$ and other measurements are expressed as either percentage of standard length or, for subunits of head, percentage of head length. Measurements and counts were taken on the left side of specimens, except when this side was damaged. Meristic data are given in the description, followed by the number of specimens for each count in parentheses. Examined specimens are listed as "alc" for alcohol-preserved specimens, "cs" for cleared and stained specimens (Taylor \& van Dyke, 1985), and “ds" for dry skeleton. Osteological terminology follows Weitzman (1962) with the exceptions noted by Birindelli \& Sabaj Pérez (2011). Institutional abbreviations are: ANSP, Academy of Natural Sciences, Philadelphia; AUM, Auburn University Natural History Museum, Auburn; BMNH, British Museum of Natural History, London; CAS, California Academy of Sciences, San Francisco; INPA, Instituto Nacional de Pesquisas da Amazônia, Manaus, AM; MAC-PAY, Ministerio de Agricultura y Cría, Instituto Nacional de Investigaciones Agricolas (INIA), Estación Experimental Amazonas, Puerto Ayacucho; MBUCV, Museo de Biología de la Universidad Central de Venezuela, Caracas; MCNG, Museo de Ciencias Naturales de UNELLEZ, Guanare; MCZ, Museum of Comparative Zoology, Cambridge; MNRJ, Museu Nacional, Universidade Federal do Rio de Janeiro, Rio de Janeiro; MZUSP, Museu de Zoologia da Universidade de São Paulo, São Paulo; UF, University of Florida, Gainesville; UFAM, Coleção de Peixes da Universidade Federal do Amazonas, Manaus.

\section{Results}

\section{Liosomadoras Fowler, 1940}

Liosomadoras Fowler, 1940: 226 [type-species: Liosomadoras morrowi Fowler, by original designation and monotypy]. Gender masculine.
Diagnosis. Liosomadoras is distinguished from all other genera of Auchenipteridae, except Spinipterus Akama \& Ferraris, 2011 and Trachycorystes Bleeker, 1858 by having spines on the posterior cleithral process ( $v s$. absent). Spinipterus is distinguished from Liosomadoras by having pectoral- and dorsal-fin spines with four rows of serrations running from base to the tip of the spines; lateral margins of skull roofing bones ornamented with a single row of spines, and groove along dorsal midline posterior to dorsal fin, in which the adducted dorsal fin rests. Trachycorystes is distinguished from Liosomadoras by having nasal dorsally expanded and visually exposed, eight branched pelvic-fin rays, and dorsal-fin spine with smooth posterior face. See discussion for additional notes on the diagnosis of the genus.

Etymology. From the greek leios meaning smooth, plus soma meaning body, in reference to the smooth body (i.e., without ossified scutes as doradids usually have), and the suffix doras, as traditionally applied to genera of the Doradidae (Fowler described Liosomadoras as belonging to the latter family, and not to Auchenipteridae). Gender masculine.

\section{Liosomadoras oncinus (Jardine, 1841)} Figs. 1-2

Arius oncinus Jardine in Schomburgk, 1841: 173, plate 4 [type locality: rio Padauiri; no types known].

Arius oncina Jardine in Schomburgk, 1841: figure legend of plate 4 [misspelled]. - Eigenmann \& Eigenmann, 1890: 266 [considered a doubtful species of Centromochlus]. - Mees, 1974: 59 [name included in a footnote removing the species from Centromochlus and Tatia].

Centromochlus oncinus Gosline, 1945: 10 [catalog, new generic combination].

Liosomadoras oncinus Mees, 1978: 270 [redescription, new generic combination]. - Burgess, 1989: 241 [ornamental fish catalog]. - Eschmeyer, 1998: 1241 [ catalog]. - Ferraris, 2003: 475 [catalog]. - Ferraris, 2007: 75 [catalog]. - Akama \& Soares-Porto, 2007: 118 [catalog, incorrectly assigning L. oncinus for Suriname and Peru].

Diagnosis. Liosomadoras oncinus is readily distinguished from $L$. morrowi by differences in color pattern. Liosomadoras oncinus has two longitudinal rows of about seven large squarish dark-brown blotches on the body in small specimens (up to $60 \mathrm{~mm} \mathrm{SL}$ ), which become pale in the center, in larger specimens. In even larger specimens, the blotches start to fragment into opened blotches and, eventually (in specimens of $100 \mathrm{~mm}$ SL or more), in widespread small spots, some still forming a fragmented open square (vs. widespread, non-organized, dark round blotches on body in specimens of all sizes), and for having a pale midlateral line on body, without dark blotches ( $v s$. midlateral line of body colored as the remaining lateral portion of body). 


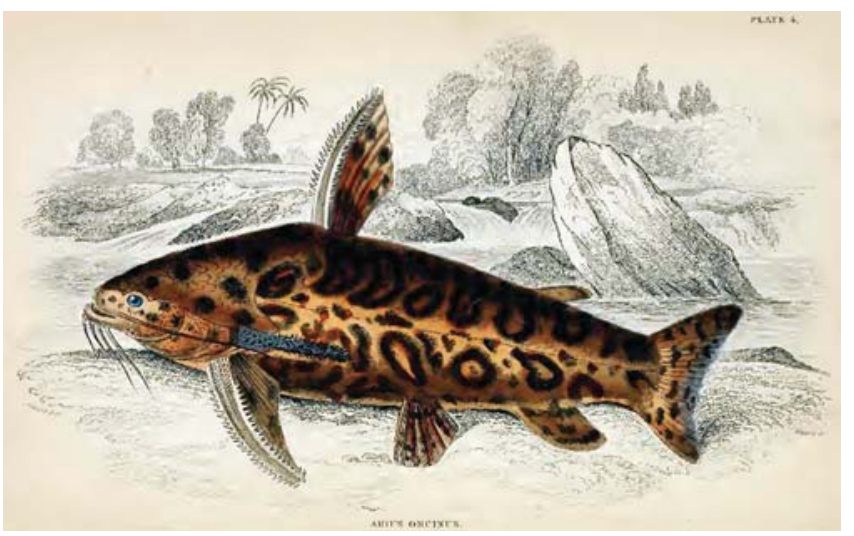

Fig. 1. Schomburgk's original drawing of Arius oncinus (Schomburgk, 1841: Fig. 4).

Description. Morphometric data for Liosomadoras oncinus is presented in Table 1. Species moderately sized (reaching up to approximately $150 \mathrm{~mm} \mathrm{SL}$ ) with a somewhat depressed head and compressed body, especially posteriorly; mouth terminal, with prognathous jaw. Eye relatively small, anterolaterally positioned on head; posterior cleithral process long, shallow, with several rows of spines. Dorsal-fin rays II,6 $(\mathrm{n}=25)$; pectoralfin rays I, 6 or 7 (mode 6, $n=25$ ); pelvic-fin rays i, $6(n=25)$; analfin rays iii, 11 or 12 (mode $11, n=25)$; caudal-fin rays i,7,8,i $(n=$ 25 ). Dorsal-fin spine robust, with approximately 20 strong spines on anterior face and about 10 weak spines on posterior face; pectoral-fin spine robust, with strong spines on both anterior and posterior faces. Axillary pore with single opening, located immediately ventral to base of posterior cleithral process. Adipose fin thick, with base slightly larger than anal-fin base. Anal fin short, with lobe length slightly greater than base length. Lateral line complete, straight to slightly sinuous anteriorly, unbranched at caudal fin, few transverse rows of free neuromasts dorsal to lateral-line canal, usually visible as clear areas on body. Caudal fin weakly forked, ventral lobe slightly larger than dorsal one. Gas bladder occupying most of dorsal portion of body (pleuroperitoneal) cavity; apple-shaped or abbreviated cordiform with internal T-shaped septum (Birindelli et al., 2009: fig. 2).

Osteology. Lateral and dorsal view of head in Fig. 3. Cranialroof bones and nuchal plates well developed and ornamented with shallow grooves and reticulated ridges. Dorsal surface of cranial-roof bones straight in lateral view, and slightly convex in frontal view, especially at nuchal region.

Mesethmoid short and wide, bifid anteriorly with cornua anterolaterally oriented, posteriorly contacting frontals (not enclosing fontanel). Mesethmoid anteriorly covered by thick skin, its middle and posterior portion covered by a thin layer of skin. Anterior cranial fontanel rounded or divided into a smaller opening anteriorly, delimited by frontals. Posterior cranial fontanel completely occluded.

Premaxilla plate-like with many minute, acicular teeth closely set in multiple, irregular rows; attached dorsally to mesethmoid cornua. Maxilla short, proximal end with hollow condylar process at base of maxillary barbel. Autopalatine short, rod-like. Nasal long, tubular, running from anterior tip of mesethmoid to suture between mesethmoid and frontal; also, possessing small laterally oriented branch located at approximately the anteriormost one-fourth of the bone.

Lateral ethmoid broad, contacting first infraorbital anterolaterally, mesethmoid medially and frontal posteromedially; covered by thick skin, except for outer margin near perimeter of orbit. Sphenotic large, contacting lateral ethmoid, thus excluding frontals from orbit. Epioccipital with a small lateral border enclosing tympanic area, and short, weakly defined posterior process. Posttemporosupracleithrum subtriangular, V-shaped ventral margin, tip articulating with dorsal process of cleithrum; conspicuous pitline in area near suture between pterotic and epioccipital; contacting only pterotic, and epioccipital (falling short from reaching middle nuchal plate).

Nuchal shield formed by anterior, middle and posterior nuchal plates, ventrally fused with neural spines of the

Table 1. Morphometric data for Liosomadoras oncinus and L. morrowi. $\mathrm{n}=$ number of analized specimens; $\mathrm{SD}=\mathrm{Standard}$ Deviation.

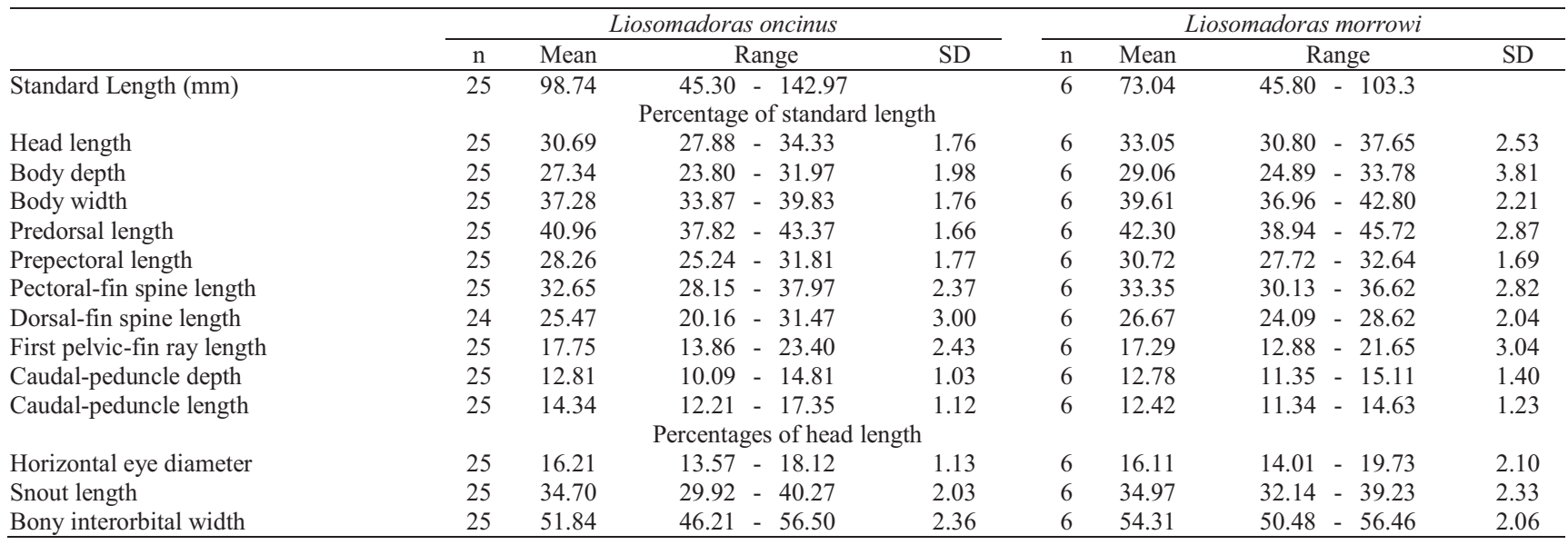




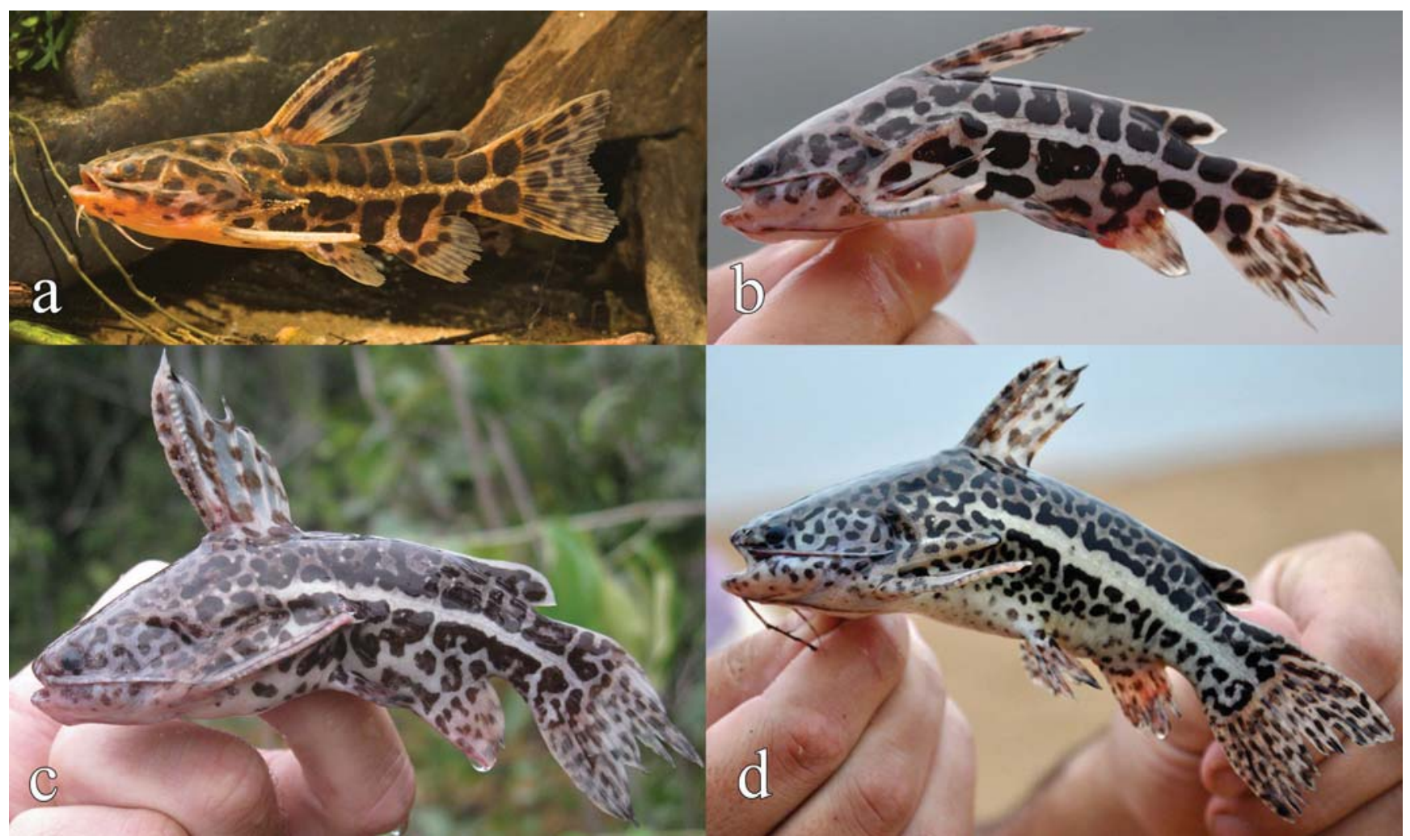

Fig. 2. Liosomadoras oncinus: (a) specimen purchased on the Aquarium trade in Montreal (photo by Oliver Lucanus); (b) and (d) AUM uncatalogued, collected with MZUSP 105828 (photo by Nathan Lujan); (c) MZUSP 105828 (nuptial male), río Ventuari, Orinoco basin. All photographed live.

complex vertebrae. Anterior nuchal plate pentagonal, with apex pointed posteriorly; anterior nuchal plate sutured to parieto-supraoccipital anteriorly, epioccipital laterally and middle nuchal plate posteriorly. Middle nuchal plate butterflyshaped, anteriorly sutured to anterior nuchal plate, and epioccipital. Lateral margins of middle nuchal plate concave. Posterior nuchal plate with lateral wings ventrally expanded; posteroventral portion attached to the infranuchal ligament (latter attached to the first rib). Tympanic area delimited by posttemporo-supracleithrum anteriorly, posterior cleithral process ventrally, middle nuchal plate dorsally and posterior nuchal plate plus infranuchal ligament posteriorly (Fig. 4).

Four infraorbitals. First infraorbital broad, with smooth anterior expansion, medially pointed towards anterolateral cornu of mesethmoid and laminar posteromedial expansion participating in orbital perimeter. Second, third and fourth infraorbitals tubular, with bony granulations on lateral face.

Dentary with teeth similar in form and arrangement to those present on premaxilla. Dentary with six ventral openings for the preoperculomandibular laterosensory canal. Coronomeckelian bone small and connected posteriorly to angulo-articular and laterally to dentary (not connected anteriorly to dentary), covering part of Meckelian cartilage.

Metapterygoid roughly trapezoidal, articulating with quadrate ventrally and hyomandibula posteriorly and to entopterygoid anterodorsally. Entopterygoid small, situated between metapterygoid and lateral ethmoid. Hyomandibula broad, dorsally articulated to sphenotic and pterotic. Quadrate relatively large, sutured to metapterygoid, hyomandibular and preopercle, and articulated with angulo-articular. Suprapreopercle absent. Opercle roughly triangular, with broad posterior border.

Urohyal relatively small, longer than wide, with strong ventral keel, and without lateral wings. Ventral hypohyal larger than dorsal hypohyal (Fig. 5); with small suture to anterior ceratohyal laterally. Anterior ceratohyal elongate, joined to posterior ceratohyal laterally via suture and medially via synchondral joint. Seven branchiostegal rays; first four articulated with the anterior ceratohyal, and last three with the posterior ceratohyal. Basibranchials 2 and 3 ossified with cartilaginous caps, the former broad and the latter elongate. Basibranchial 4 entirely cartilaginous, roughly hexagonal. Three hypobranchials, first two partially ossified, third (posteriormost) entirely cartilaginous; first hypobranchial rodlike, with cartilage caps restricted at medial and lateral end. Five ceratobranchials ossified, elongate, with cartilaginous caps at both ends; fifth ceratobranchial with middle portion broad, bearing lower pharyngeal plate with many acicular teeth. Four or five epibranchials, first two elongate, third with well-developed uncinate process posteromedially oriented, fourth possessing small dorsal expansion; fifth epibranchial greatly reduced and cartilaginous (INPA 35453), or entirely 


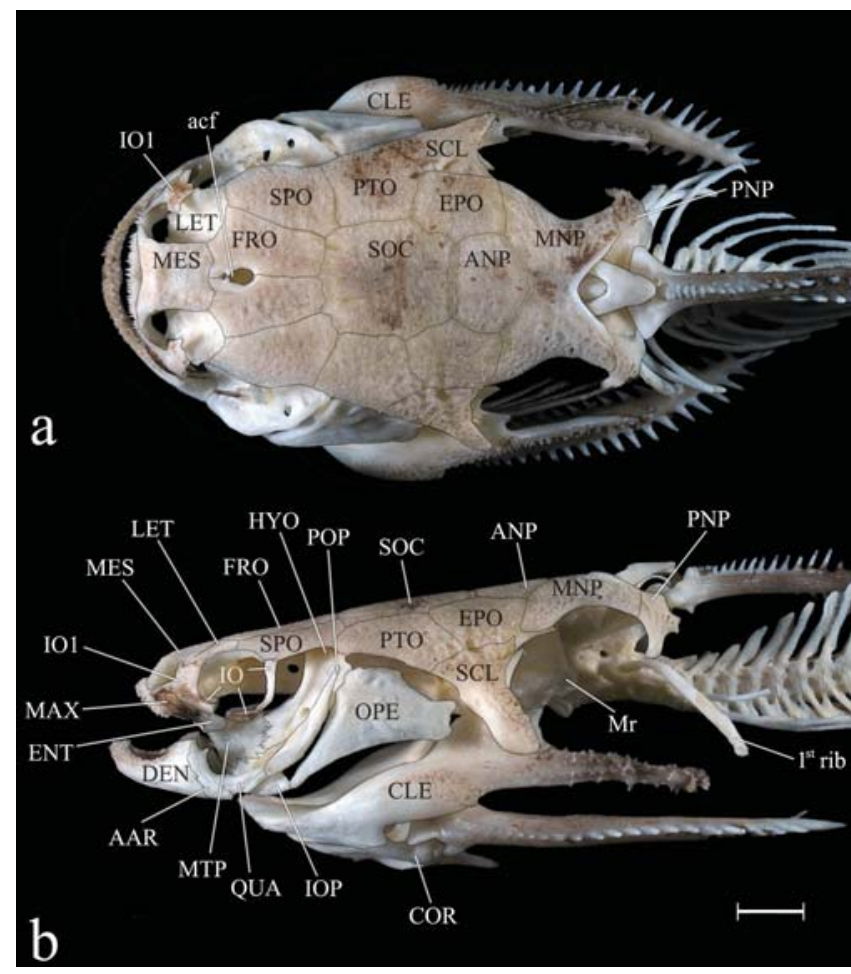

Fig. 3. Head in dorsal (a) and lateral (b) view of Liosomadoras oncinus, MZUSP 105828, $99 \mathrm{~mm}$ SL. AAR = angulo-articular, acf anterior cranial fontanel; ANP anterior nuchal plate, CLE $=$ cleithrum, $\mathrm{COR}=$ coracoid, $\mathrm{DEN}=$ dentary, $\mathrm{ENT}=$ entopterygoid, $\mathrm{EPO}=$ epioccipital, $\mathrm{FRO}=$ frontal, $\mathrm{HYO}=$ hyomandibular, $\mathrm{IO}=$ infra-orbital, $\mathrm{IOP}=$ interopercle, $\mathrm{LET}=$ lateral ethmoid, $\mathrm{MAX}=$ maxilla, $\mathrm{MES}=$ mesethmoid, $\mathrm{MNP}=$ middle nuchal plate, $\mathrm{Mr}$ Müllerian ramus, $\mathrm{MTP}=$ metapterygoid, $\mathrm{OPE}=$ opercle, $\mathrm{PNP}=$ posterior nuchal plate, $\mathrm{POP}=$ preopercle, $\mathrm{PTO}=$ pterotic, $\mathrm{QUA}=$ quadrate, $\mathrm{SCL}=$ posttemporo-supracleithrum, $\mathrm{SOC}=$ parietosupraoccipital, $\mathrm{SPO}=$ sphenotic. Scale bar $=5 \mathrm{~mm}$.

absent (MZUSP 93497). Pharyngobranchials 1 and 2 absent. Cartilaginous nodule joining medial ends of epibranchials 1 and 2 and anterior tip of pharyngobranchial 3 . Pharyngobranchials 3 and 4 ossified; third elongate, with posterior extremity broad; fourth short and broad. Upper pharyngeal tooth plate oval, bearing many ventrally directed acicular teeth. First four gill arches with two rows of approximately 15 minute rakers; last gill arch with only an anterior row of approximately eight rakers.

Total vertebrae $39(n=2)$ or $40(n=1)$. Complex vertebra completely sutured to fifth, sixth, and seventh vertebrae, and partially to eighth vertebra; first completely free vertebra is ninth. Aortic passage enclosed by superficial ossification $(\mathrm{n}=3)$, and ventrally keeled. Müllerian ramus round, broad, oriented about $45^{\circ}$ to longitudinal body axis. Vertebra 5 with pair of process-like parapophyses directed posterolaterally. Vertebrae 6 to 14 or 15 bearing ribs.

Pectoral girdle strong, broad, with well-developed dorsal, posterodorsal, and posterior processes of

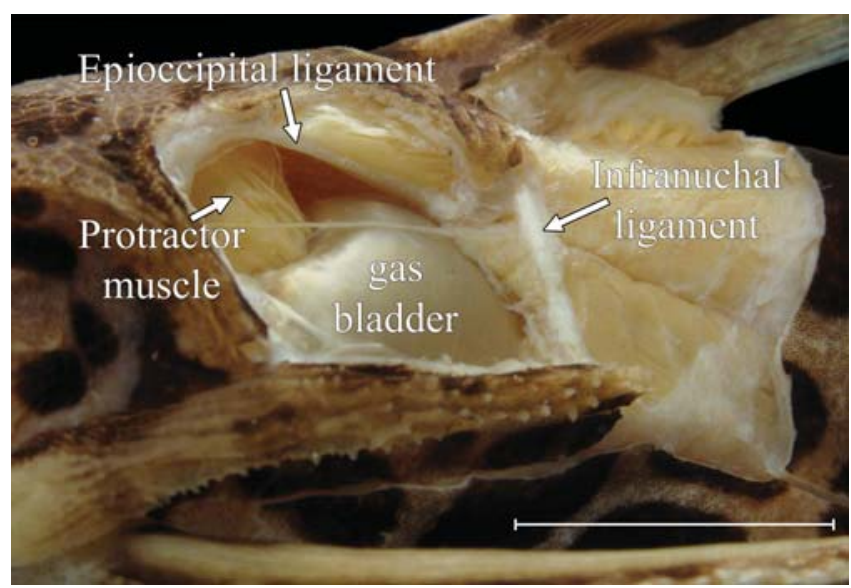

Fig. 4. Tympanic area in lateral view of Liosomadoras oncinus, MZUSP 93497, 74.8 mm SL. Scale bar $=10 \mathrm{~mm}$.

cleithrum, and relatively short coracoid process (Fig. 6). Posterior cleithral process elongate (length more than six times depth), ornamented with denticulate longitudinal ridges. In ventral view, girdle completely covered by muscle layers. Bony crest (keel) on ventral surface of coracoid oriented at approximately $45^{\circ}$ to longitudinal axis of body, separating abductors superficialis and arrector ventralis muscles. Two proximal radials ossified, elongate, rod-like. One or two distal radials cartilaginous (hardly visible in the examined cs specimens). Pectoral spine with antrorse serrations along anterior margin and retrorse along posterior margin.

Basipterygium subtriangular (Fig. 7), external and internal anterior processes long, roughly straight, rod-like; external process longer. Lateral process weakly developed. Posterior process small, short, ossified. Cartilaginous cap along medial, posterior and posterolateral margins of basipterygium.

Anal fin with12-13 pterygiophores (Fig. 8), all rod-like except last one, broad and supporting 2-3 rays. Caudal skeleton with parhypural, hypural 1 and hypural 2 fused, forming a single ventral plate, which is in turn fused to compound centrum (Fig. 9). Hypural 3 and 4 fused, but not fused to compound centrum; hypural 5 independent. Hypurapophysis of type C following Lundberg \& Baskin (1969).

Coloration. Ground color tan to cream laterally and brown dorsally; sometimes more yellowish, other times grayish. Small specimens (up to $60 \mathrm{~mm} \mathrm{SL}$ ) with two longitudinal rows of about seven large squarish dark-brown blotches on body and smaller blotches on head and fins. In larger specimens, blotches become pale inside and start to fragment into opened blotches and then, eventually, into widespread small spots, some still forming a fragmented open square (in specimens of $100 \mathrm{~mm} \mathrm{SL}$ or more; Fig. 2). Midlateral line of body pale, without dark blotches, from tympanic area to caudal-fin base. Neuromasts of lateral line and transversal lines dorsal to lateral line with pale border. Ventral portion of head and abdomen pale cream, usually without spots, or rarely with few dark spots. 


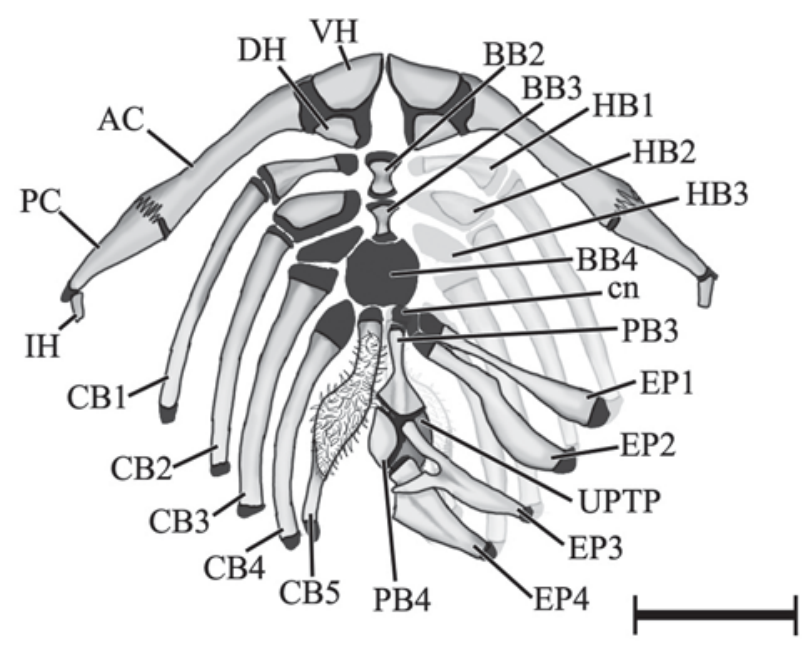

Fig. 5. Schematic illustration of the hyoid and branchial arches in dorsal view of Liosomadoras oncinus, based on MZUSP 93497, 70.7 mm SL. Left side of dorsal branchial arches omitted for ease of understanding. Urohyal and branchiostegal rays not represented. $\mathrm{AC}=$ anterior ceratohyal, $\mathrm{BBn}$ basibranchials, $\mathrm{CBn}=$ ceratobranchials, $\mathrm{cn}$ = cartilaginous nodule, $\mathrm{DH}=$ dorsal hypohyal, Epn = epibranchials, $\mathrm{HBn}=$ hypobranchials, $\mathrm{IH}=$ interhyal, $\mathrm{PBn}=$ pharyngobranchials, PC = posterior ceratohyal, UPTP = upper pharyngobranchial tooth plate, $\mathrm{VH}=$ ventral hypohyal. Scale bar $=5 \mathrm{~mm}$.

Coloration in live specimens very similar to that described above based on alcohol-preserved specimens, except that live specimens have more conspicuous dark blotches over pale yellow background.

Sexual dimorphism. Nuptial males of Liosomadoras oncinus exhibit the dorsal fin with an irregular row of serrations on the anterior face and the capacity of moving it far forward, at an angle of more than $90^{\circ}$. As in other Auchenipterinae, nuptial males of Liosomadoras oncinus also have the genital papilla as a tube attached to the anterior border of the anal fin and opening at the distal edge of last unbranched ray.

Distribution. Liosomadoras oncinus is known from the rio Negro basin (including rio Branco) from Barcelos, Amazonas upstream to near the mouth of rio Içana, in Brazil, and upper rio Orinoco in the río Ventuari, río Casiquiare and río Atapabo, in Venezuela (Fig. 10). Royero (1999) listed specimens of Liosomadoras oncinus collected in the río Casiquiare (MBUCV 26062; MCNG 12150), and its tributaries río Siapa (MCNG 12309 , MCNG 25970) and río Pasimoni(MAC-PAY2295, MCNG 12437).

Ecology. There is no comprehensive published information on the biology and ecology of Liosomadoras oncinus in its natural habitat. Specimens collected by us were found in cavities and nooks of submerged tree trunks of black water rivers, such as rio Negro, and swamp forest (igapós) of clear

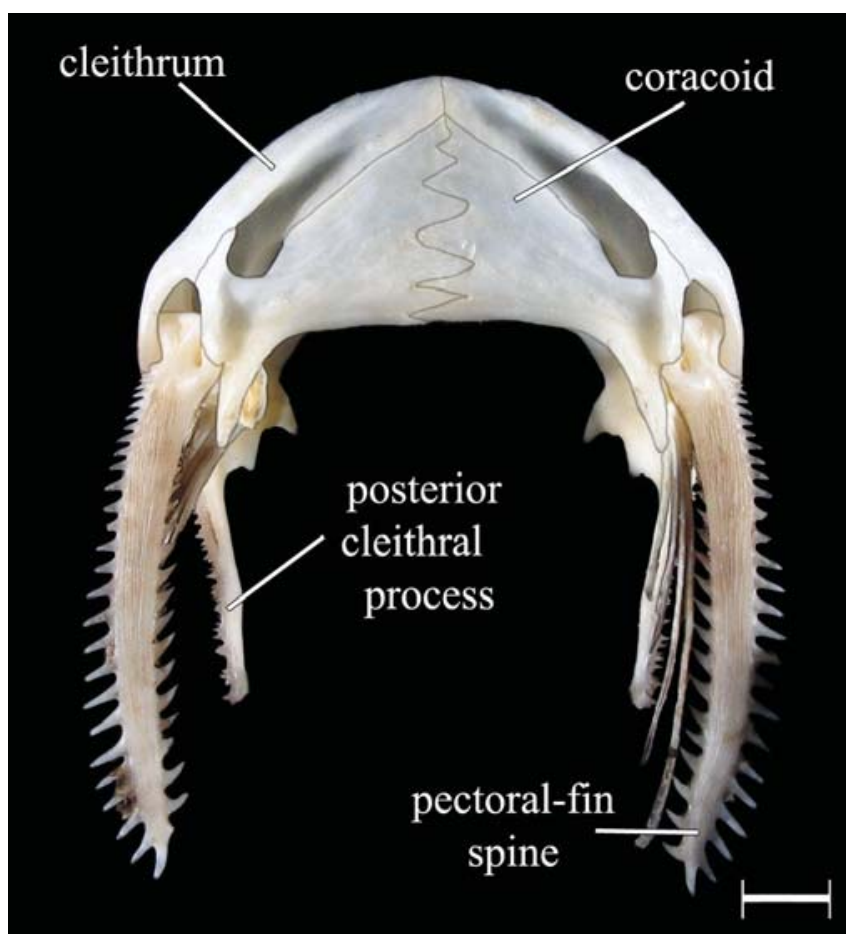

Fig. 6. Pectoral girdle in ventral view of Liosomadoras oncinus, MZUSP 105828, $99 \mathrm{~mm}$ SL. Scale bar $=5 \mathrm{~mm}$.

water rivers, such as río Ventuari. Aquarium observations indicate that the species is carnivorous.

Etymology. Named in reference to the overall color pattern, noticeably similar to the color pattern of the South American Jaguar Panthera onca.

\section{Liosomadoras morrowi Fowler, 1940}

Fig. 11

Liosomadoras morrowi Fowler, 1940: 226 [type locality: Ucayali river basin, Contamana, Peru]. - Gosline, 1945: 15 [catalog, included in Doradidae] - Rössel, 1962: 30 [name mentioned in text as considered to belong to the family Auchenipteridae, instead of Doradidae]. - Mees, 1978: 272 [considered junior synonym of Arius oncinus]. - Burgess, 1989: 241 [ornamental fish catalog]. - Burgess, 1994: 90 [revalidation, based on live Aquarium specimens, not preserved in fish collections]. - Eschmeyer, 1998: 1123 [catalog] - Ferraris, 2003: 475 [catalog, considered a valid species]. - Ferraris, 2007: 75 [catalog].

Diagnosis. Liosomadoras morrowi is readily distinguished from $L$. oncinus by the coloration, L. morrowi having widespread (non-organized) dark round blotches on body in specimens of all sizes ( $v s$. two longitudinal rows of about seven large squarish dark-brown blotches on body in small specimens [up to $60 \mathrm{~mm} \mathrm{SL}$ ], which during growth become pale inside and start to fragment into opened blotches and 


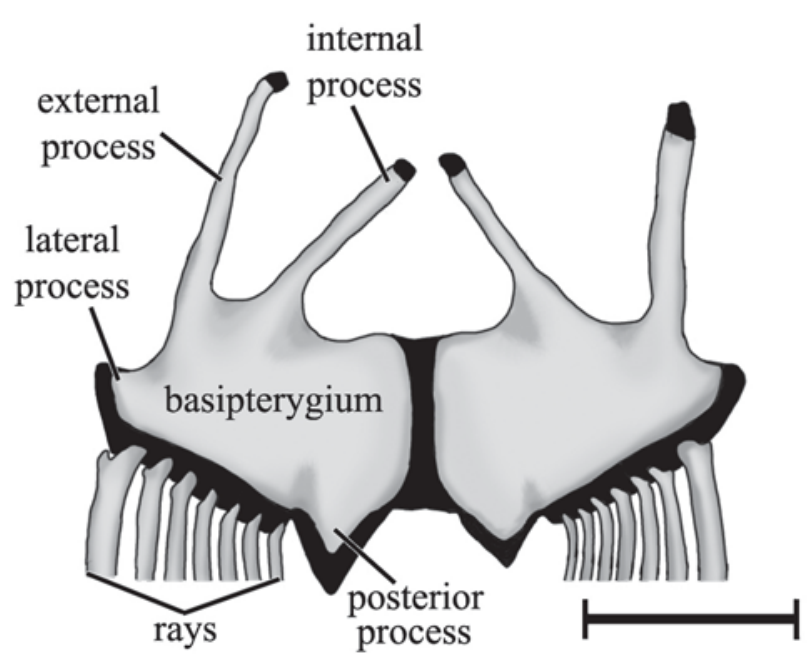

Fig. 7. Schematic illustration of the pelvic girdle in dorsal view of Liosomadoras oncinus, based on MZUSP 105828, $101 \mathrm{~mm}$ SL. Scale bar $=5 \mathrm{~mm}$.

then, eventually, into widespread small spots, some still forming a fragmented open square [in specimens of $100 \mathrm{~mm}$ SL or more]), and for having midlateral line of body colored as the remaining lateral portion of body ( $v s$. midlateral line of body pale, without dark blotches or spots).

Description. Morphometric data for Liosomadoras morrowi is presented in Table 1. Species moderately sized (largest examined specimen $103.3 \mathrm{~mm} \mathrm{SL}$ ) with somewhat depressed head and body, terminal mouth with prognathous jaw. Eye relatively small, anteriorly positioned on head; posterior cleithral process long, shallow, with several rows of spines. Dorsal-fin rays II, $6(n=6)$; pectoral-fin rays I, $6(n=6)$; pelvic-fin rays i,6 $(n$ $=6$ ); anal-fin rays iii, 10 or 11 (mode $11, \mathrm{n}=6$ ); caudal-fin rays i,7,8,i $(n=6)$. Dorsal-fin spine robust, with approximately 20 strong serrations on anterior face and about 10 on posterior face; pectoral-fin spine robust, with strong serrations on both anterior and posterior faces. Axillary pore with single opening, located immediately ventral to base of posterior cleithral process. Adipose fin thick, with base slightly larger than analfin base. Anal fin short, with lobe length slightly larger than base length. Lateral line complete; few transverse rows of free neuromasts dorsal to lateral-line canals, usually visible as clear areas on body. Caudal fin weakly forked, ventral lobe slightly larger than dorsal one. Gas bladder occupying most of dorsal portion of body (pleuroperitoneal) cavity; appleshaped or abbreviated cordiform with internal T-shaped septum (Birindelli et al., 2009: fig. 2).

Coloration. Ground color tan to brown or gray, slightly countershaded. Large round dark blotches widespread (and unorganized) on body, head and fins. Dark blotches larger than eye diameter, and proportionally larger in smaller specimens (Fig. 11). Neuromasts of lateral line and transversal

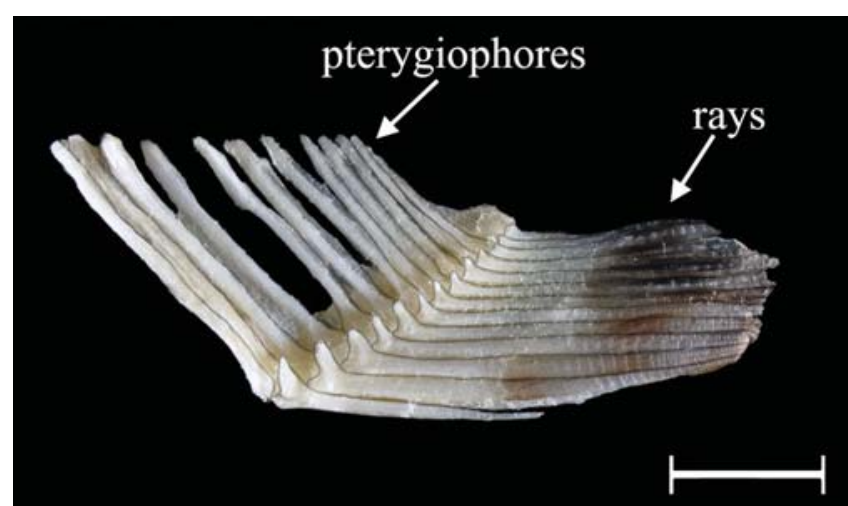

Fig. 8. Anal fin in lateral view of a nuptial male of Liosomadoras oncinus, MZUSP 105828, $99 \mathrm{~mm}$ SL. Scale bar $=5 \mathrm{~mm}$.

lines dorsal to lateral line with pale border. Ventral portions of head and abdomen pale cream, usually without spots.

Although no live specimen was examined, in the available illustration of a live specimen (Burgess, 1989: 88, unnumbered figure), the coloration is similar to described above based on alcohol-preserved specimens, except for being overall darker.

Sexual dimorphism. No nuptial male was available for inspection. However, a non-nuptial male show a modified anal fin as in other Auchenipterinae, with the genital papilla located in a tube attached to the anterior border of the anal fin, and opening at the distal edge of the last unbranched ray.

Distribution. Liosomadoras morrowi is known from the río Ucayali basin, from Contamana to Iquitos, in eastern Peru, and from the rio Jutaí, rio Purus, and Lago Amanã near Tefé, in northwestern Brazil.

Ecology. As with Liosomadoras oncinus, there is no published information on the biology and ecology of $L$. morrowi in its natural habitat. Specimens were collected in cavities of submerged tree trunks (INPA 25415), or in association with floating macrophyte mats (INPA 35282).

Etymology. Named in honor of Mr. William C. Morrow, who collected the type specimen in an expedition in Peru in July and August, 1937. As a result of that expedition, a total of 319 specimens belonging to 106 species were sent to Henry W. Fowler at the Academy of Natural Sciences of Philadelphia, who described 22 species and five genera as new, including Liosomadoras morrowi.

\section{Discussion}

Both species of Liosomadoras are very similar in overall body shape, morphometric and meristic data. However, they are conspicuously distinct in coloration, as already noticed in articles published in aquarium magazines (Burgess, 1989; Finley, 1997). Several other examples of closely related 


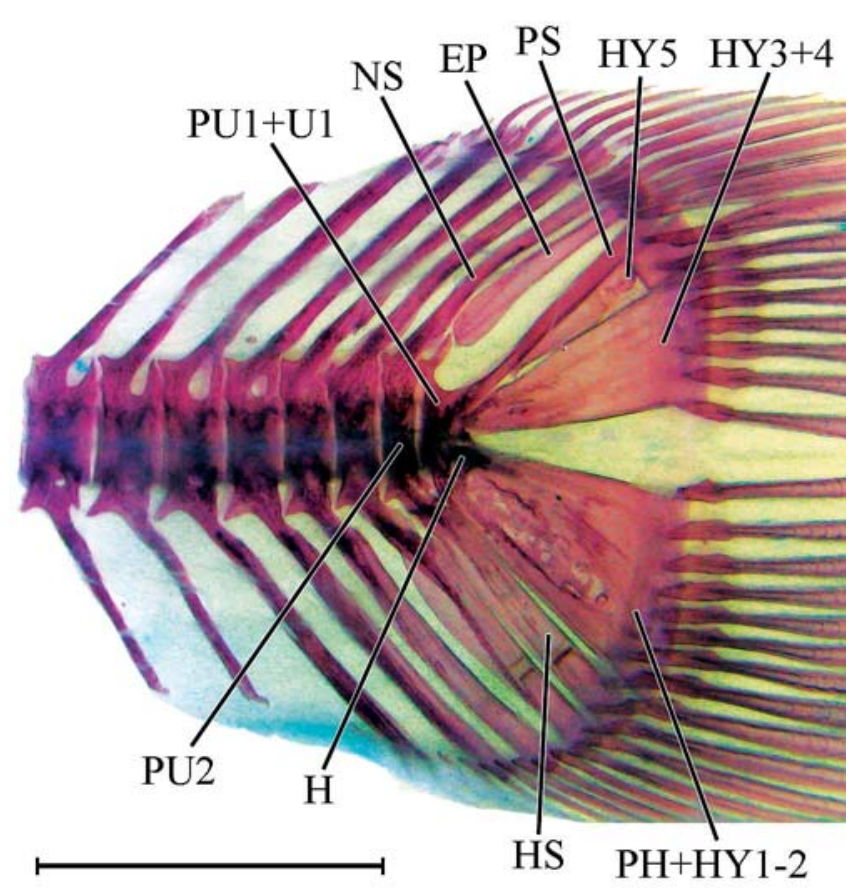

Fig. 9. Caudal skeleton in lateral view of Liosomadoras oncinus, MZUSP 105828, $99 \mathrm{~mm}$ SL. EP = epural, $\mathrm{H}=$ hypurapophysis, $\mathrm{HS}=$ hemal spine, $\mathrm{HY}=$ hypural, $\mathrm{NS}=$ neural spine, $\mathrm{PH}=$ parhypural, $\mathrm{PS}=$ pleurostyle, $\mathrm{PU} 1+\mathrm{U} 1=$ fused first preural and first ural centra, $\mathrm{PU} 2=$ second preural centra. Scale bar $=5 \mathrm{~mm}$.

species of catfishes that are distinguished only by the coloration are known. That is the case of Auchenipterichthys longimanus and A. punctatus (Ferraris et al., 2005), species of Pseudolithoxus (Lujan \& Birindelli, 2011), species of Trichomycterus (Barbosa \& Costa, 2010), and species of Corydoras (Nijssen \& Isbrücker, 1986), to name a few.

The validity of the two species is also supported by their apparently allopatric distribution. Liosomadoras oncinus is restricted to the rio Negro and upper Orinoco basins, whereas L. morrowi occurs in the Amazon basin above Manaus. Similar allopatric distributions were already described for other species of fishes, such as those of Symphysodon (Ready et al., 2006) and Scorpiodoras (Sousa \& Birindelli, 2011). The distributional gap between closely related species along the main channel of the rio Solimões, between the mouth of rio Tefé and rio Negro, is possibly related to the formation of the Purus arch. The latter was once an upland drainage divide between the eastern and western portions of the Amazon region. After it was breached in the Late Miocene (about 8 million years ago) the modern rio Amazonas that flows from the Andes eastward to the Atlantic Ocean was formed (Lundberg, 1998). Nowadays, the Purus arch restricts the channel of the rio Solimões to a valley less than $20 \mathrm{~km}$ wide, compared to a width of approximately $45 \mathrm{~km}$ outside this region (Mertes et al., 1996). The narrow valley restricts the local floodplain of the rio Solimões and thus

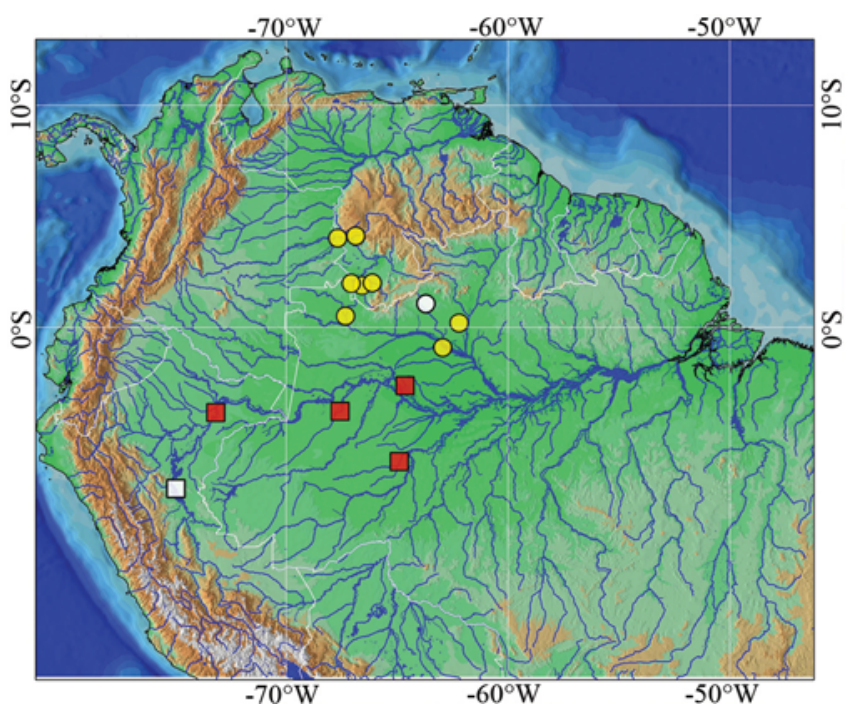

Fig. 10. Distribution of the species of Liosomadoras, L. oncinus represented by yellow circles, and L. morrowi by red squares. Type locality represented by open symbols.

decreases the availability of lowland "várzea" habitats (i.e., flooded forest) where Liosomadoras are usually found.

The Auchenipteridae is divided into Centromochlinae and Auchenipterinae, which are both well-corroborated monophyletic groups (Ferraris, 1988, 2003). The Centromochlinae includes only Centromochlus, Gelanoglanis, Glanidium, and Tatia (Ferraris, 2003; Eschmeyer, 2010) and is diagnosed by the following non-homoplastic three synapomorphies: modified anal-fin rays and pterygiophores with posterior orientation; urogenital papilla of adult males emerging from a skin flap at anal-fin base; and anal-fin pterygiophores conjoined, partially or completely fused together (Soares-Porto, 1998). The Auchenipterinae includes all the remaining genera of the family and is diagnosed by a single synapomorphy: urogenital papilla of nuptial males attached to the anterior margin of the anal fin, with its opening usually at the tip of first anal-fin rays (Ferraris, 1988; Birindelli, 2010). Two synapomorphies define a large monophyletic group that includes all genera of Auchenipterinae, with the exception of Tocantinsia, Liosomadoras, and Asterophysus: (1) first anal-fin rays elongate and thickened in nuptial males, and (2) anal fin with 15 or more branched rays (Birindelli, 2010). The first character is present in all species of Auchenipterinae, with the exception of Entomocorus, Asterophysus, Tocantinsia, and Liosomadoras, and the second in all but Pseudotatia, Asterophysus, Tocantinsia, and Liosomadoras. Pseudotatia is a monotypic genus known only from few specimens, and probably related to Pseudauchenipterus (Akama, 1999; Birindelli, 2010). Although Entomocorus has several plesiomorphic characters for species of Auchenipteridae, which make its placement among auchenipterids somewhat problematic (Reis \& Borges, 2006), the genus is considered to be related to Auchenipterus, 


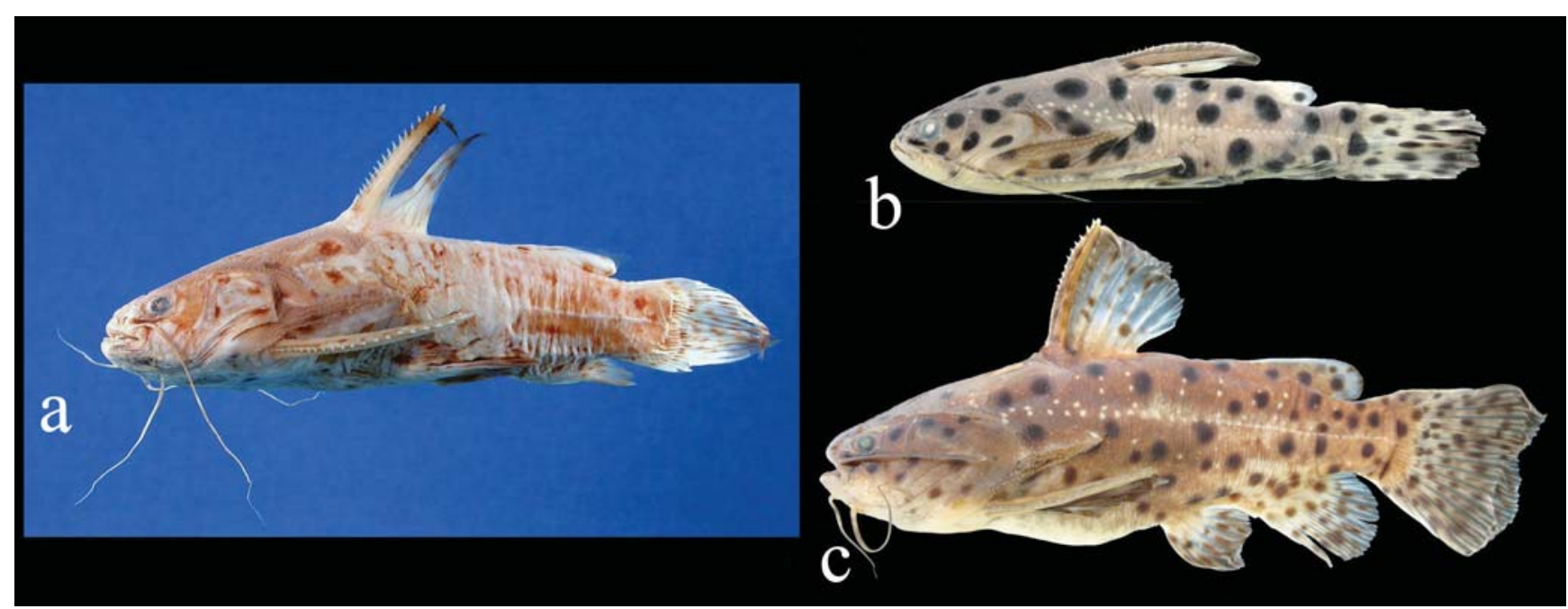

Fig. 11. Liosomadoras morrowi: (a) holotype, ANSP 68646, $76 \mathrm{~mm}$ SL, río Ucayali basin, Contamana, Peru (photo by K. Luckenbill); (b) INPA uncatalogued, 45.8 mm SL, rio Jutaí (351'39.5”'S 67³4’45.9”'W), Amazonas, Brazil; (c) UF 117251, 95.2 $\mathrm{mm}$ SL, río Nanay, Loreto, Peru.

Epapterus and Pseudepapterus, based on numerous synapomorphies (Ferraris, 1988; Royero, 1999; Akama, 2004; Reis \& Borges, 2006; Birindelli, 2010). For lacking the two synapomorphies present in most species of the Auchenipterinae, Liosomadoras, Tocantinsia, and Asterophysus most likely occupy a basal position in the subfamily (Birindelli, 2010).

The genus Spinipterus was recently described based on a single young adult male. According to Akama \& Ferraris (2011), Spinipterus shares some characters that suggest that it may have a close relationship to Trachelyopterichthys, including large anterior fontanel, short dorsal-fin spine, and preopercle and infraorbital 1 covered by spines. Spinipterus also shares some putatively derived character states with Liosomadoras and Trachycorystes, including the presence of spines on the posterior cleithral process (Akama \& Ferraris, 2011; see other shared characters below). Nevertheless, the understanding of the phylogenetic relationships of Spinipterus is limited due to the lack of specimens for osteological studies as well as the lack of mature males for examination of characters related to sexually dimorphic features.

The monophyly of Liosomadoras is supported by one homoplastic synapomorphy among auchenipterids: the presence of spines on the posterior cleithral process. The only other auchenipterid genera showing a somewhat similar condition are Trachycorystes and Spinipterus. The presence of distinct spines on the posterior cleithral process was used by Higuchi et al. (2007) to diagnose the doradid subfamily Astrodoradinae. The Astrodoradinae, Liosomadoras, Trachycorystes, and Spinipterus are relatively distal taxa within their families (Birindelli, 2010). Thus, the presence of spines on the posterior cleithral process is best interpreted as convergent, but still diagnostic for each of those groups.

Several other characters present in Liosomadoras are relevant for determining the phylogenetic position of the genus. However, the optimization of those characters varies among phylogenetic hypotheses (Ferraris, 1988; Royero, 1999; Akama, 2004; Birindelli, 2010). These characters are described below and their occurrences in species of Auchenipteridae are mentioned. An enlarged dorsal-fin spine with an irregular row of serrations on the anterior face in nuptial males, and the capacity of moving anteriorly that spine more that $90^{\circ}$ in relation to the body axis, is present only in Liosomadoras, Ageneiosus, Auchenipterus, Entomocorus, Trachelyopterus, Tetranematichthys, Pseudepapterus, and Epapterus. The combination of the strong anterior serrations and amplified dorsal-fin spine mobility indicate that the dorsal fin may help seizing the females during mating. Such a mechanism is known to occur in other auchenipterids (Burgess, 1989; Akama, 2004). In the Auchenipteridae there is a huge variation in the number of pelvic-fin rays. Liosomadoras, Pseudotatia, Spinipterus, Tocantinsia, Tetranematichthys, and Ageneiosus are the only taxa of the family with six branched rays on the pelvic fin. Trachelyopterus, Spinipterus, Entomocorus, and the Centromochlinae have only five rays and all other auchenipterids have seven or more (Britski, 1972; Ferraris, 1988; Royero, 1999; Akama, 2004).

The posterior process of the epioccipital is not ossified in Liosomadoras, Tocantinsia, Trachycorystes, Spinipterus, and in the Centromochlinae, whereas it is ossified in all other auchenipterids. The lateral line is branched at the caudal-fin origin in all auchenipterids except Liosomadoras, Pseudotatia, Pseudauchenipterus, Tocantinsia, Trachelyichthys, Auchenipterichthys, Trachelyopterichthys, Entomocorus, Spinipterus, and Centromochlinae (Britski, 1972; Ferraris, 1988; Royero, 1999; Akama, 2004). In Liosomadoras, Asterophysus, Auchenipterichthys, 
Trachelyopterus, Trachycorystes, Spinipterus, Trachelyopterichthys, Auchenipterus, Entomocorus, Epapterus, and Pseudepapterus, the lateral border of the cranium at the orbit is composed by the lateral ethmoid and sphenotic instead of the lateral ethmoid and frontal (Britski, 1972; Ferraris, 1988; Royero, 1999; Akama, 2004). Two rows of diminutive rakers on the first two gill arches are found in Liosomadoras, Pseudauchenipterus, Trachycorystes, Asterophysus, Auchenipterichthys, Trachelyopterichthys, and Trachelyichthys (Britski, 1972; Royero, 1999; Akama, 2004; condition unknown for Spinipterus), whereas other auchenipterids have only a single row.

\section{Material examined. Liosomadoras morrowi: ANSP 68646} (holotype, $76 \mathrm{~mm} \mathrm{SL}$ ), río Ucayali basin, Contamana, Peru, JulAug 1937, W. C. Morrow. INPA uncatalogued (2, 45.8-53.8 mm SL), rio Jutaí (351'39.5'S 67³4'45.9”W), Amazonas, 25 Aug 2008, H. Bleher. INPA 35282 (1, 49.3 mm SL), Lago Amanã, mouth of Igarapé Juá Grande, Tefé, Amazonas, Brazil, 29 Nov 2002, J. Zuanon et al. INPA 35415 (1, $103.3 \mathrm{~mm} \mathrm{SL})$, Lago do Veado, rio Caniuá, at Aldeia Açaí in the Terra Indígena Paumari $\left(6^{\circ} 8^{\prime} 18^{\prime \prime S}\right.$ 6453'29”W), Tapauá, Amazonas, Brazil, 16 Nov 2010, F. Rossoni et al. UF 117251 (2, 90.9-95.2 mm SL), río Nanay, near Mixana, Loreto, Peru, 30 Mar 2001, J. S. Albert. Liosomadoras oncinus: ANSP 190707 (2, 38.0-76.0 mm SL), Caño Tigre, tributary of río

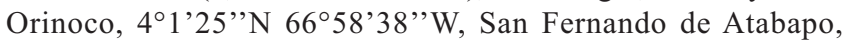
Amazonas, Venezuela, 31 Mar 2010, M. H. Sabaj Pérez et al. AUM 44117 (1, not measured), Caño Gaupa Sucia, tributary of río Atabapo, $2.3 \mathrm{~km}$ of San Fernando de Atabapo, Amazonas, Venezuela, 4 Apr 2005, N. K. Lujan et al. BMNH 1985.7.26.1 (1, $133.0 \mathrm{~mm}$ SL), purchased in Aquarium shop. CAS 36642 (2, 73.6-114.0 mm $\mathrm{SL})$, rio Negro, upstream from Manaus, purchased from Cardinal Aquarium in Manaus, Amazonas, Brazil. CAS 35112 (1, not measured), rio Xeruini, at Lago de Massai, $c a$. $10 \mathrm{~km}$ from Santa Angela, ca. $50 \mathrm{~km}$ upstream from mouth, AM, Brazil, 5 May 1964, Brittan, M. R. \& H. W. Schwartz. INPA 35453 (1 cs, 70.7 mm SL), rio Negro, at Anavilhanas, Novo Airão, Amazonas, Brazil, 1 Nov 1991, J. Zuanon et al. INPA 35536 (3, 45.3-60.0 mm SL), Igarapé Aduiá, tributary of rio Negro (0²6'2"S 6319'9'”W), 15 Jan 2007 , J. A. Gomes et al. MAC-PAY 4982 (3, not measured), río Casiquiare, 30 Aug 2007, J. Fernandez. MCZ 65742 (8, 60.8-131.0 mm SL, 2 cs, 60-65 mm SL), Amazon basin, Brazilian Aquarium Exporter, Feb 1987. MNRJ 12351 (9, 77.5-142.9 mm SL), rio Negro ( $0^{\circ} 20^{\prime} \mathrm{N}$ 67¹9’W), Inambu, Amazonas, Brazil, 24-30 Jul 1991, D. M. Teixeira. MNRJ 17640 ( $1 \mathrm{cs}, 125 \mathrm{~mm}$ SL), no data. MZUSP 46015 (1, $55.4 \mathrm{~mm} \mathrm{SL})$, purchased in Aquarium shop. MZUSP 93497 (2, 65.8-74.8 mm, $1 \mathrm{cs}, 70.7 \mathrm{~mm}$ ), purchased from ornamental fish exporters. MZUSP 105828 (3 sk, 99-101 mm SL), río Venturai (44'39'N 6652'6'”W), Amazonas, Venezuela, 15 Apr 2010, N. K. Lujan et al. UFAM uncatalogued (4, 68.0-98.0 mm SL), rio Negro. UFAM uncatalogued (4, 48.5-101.7 mm SL), Igarapé Zamula, tributary of rio Negro ( $0^{\circ} 5^{\prime} 57^{\prime}$ 'S $62^{\circ} 46^{\prime} 31$ ' W), Barcelos, Amazonas, Aug 2010, N. L. Chao. UFAM uncatalogued (14, 79.4$136.9 \mathrm{~mm} \mathrm{SL})$, Igarapé Daraquá, tributary of rio Negro $\left(0^{\circ} 28^{\prime} 27\right.$ 'S 6311'21'’W), Barcelos, AM, F. B. Sousa.

\section{Acknowledgements}

We thank Carl Ferraris Jr. for comments and suggestions to the manuscript. Thanks are also due to Mark S. Pérez and
John Lundberg (ANSP), Dave Catania (CAS), Karsten Hartel (MCZ), Jonathan Armbruster (AUM), Larry Page (UF), Oliver Crimmen, and James Maclaine (BMNH), Marcelo Britto and Paulo Buckup (MNRJ), Lucia R. Py-Daniel and Marcelo Rocha (INPA), Fabrício Sousa and Labish Chao (UFAM) for the hospitality during visits to the fish collections under their care and for loan of specimens when visits were not possible. We also thank Oliver Lucanus for information regarding ornamental fish trade, and for providing pictures of live specimens, and Nathan Lujan for inviting JLOB to an expedition in Venezuela, in April 2010, and also for offering pictures of live specimens. JLOB was funded by FAPESP (06/53737-7), and JZ by CNPq (307464/2009-1).

\section{Literature Cited}

Akama,A. 1999. Sistemática do gênero Pseudauchenipterus Bleeker, 1862 (Siluriformes, Auchenipteridae). Unpublished M.Sc. Dissertation, Universidade de São Paulo, São Paulo, 123p.

Akama, A. 2004. Revisão sistemática dos gêneros Parauchenipterus Bleeker, 1862 e Trachelyopterus Valenciennes, 1840 (Siluriformes, Auchenipteridae). Unpublished Ph.D. Dissertation, Universidade de São Paulo, São Paulo, 375p.

Akama, A. \& C. J. Ferraris Jr. 2003. Entomocorus melaphareus, a new species of auchenipterid catfish (Osteichthyes: Siluriformes) from the lower and middle reaches of the rio Amazonas. Neotropical Ichthyology, 1: 77-82.

Akama, A. \& C. J. Ferraris, Jr. 2011. Spinipterus, a new genus of small, spiny catfish (Siluriformes: Auchenipteridae) from the Peruvian Amazon. Zootaxa, 2992: 52-60.

Akama, A. \& L. M. Soares-Porto. 2007. Família Auchenipteridae. Pp. 116-120. In: Buckup, P. A., N. A. Menezes \& M. S. Ghazzi (Eds.). Catálogo das espécies de peixes de água doce do Brasil. Rio de Janeiro, Museu Nacional, 195p.

Barbosa, M. A. \& W. J. E. M. Costa. 2010. Seven new species of the catfish genus Trichomycterus (Teleostei: Siluriformes: Trichomycteridae) from southeastern Brazil and redescription of T. brasiliensis. Ichthyological Exploration of Freshwaters, 21: 97-122.

Birindelli, J. L. O. 2010. Relações filogenéticas da superfamília Doradoidea (Ostariophysi, Siluriformes). Unpublished Ph.D. Dissertation, Universidade de São Paulo, São Paulo, 376p.

Birindelli, J. L. O., L. M. Sousa \& M. H. Sabaj Pérez. 2009. Morphology of the gas bladder in thorny catfishes (Siluriformes: Doradidae). Proceedings of the Academy of Natural Sciences of Philadelphia, 158: 261-296.

Birindelli, J. L. O. \& M. H. Sabaj Pérez. 2011. Ossancora, new genus of thorny catfish (Teleostei: Siluriformes: Doradidae) with description of one new species. Proceedings of the Academy of Natural Sciences, 161: 117-152.

Britski, H. A. 1972. Sistemática e evolução dos Auchenipteridae e Ageneiosidae (Teleostei, Siluriformes). Unpublished Ph.D. Dissertation, Universidade de São Paulo, São Paulo, 142p.

Brittan, M. 1976. The jaguar catfish, Centromochlus species. Tropical Fish Hobbyist, 24: 36-40.

Burgess, W. E. 1989. An Atlas of Freshwater and Marine Catfishes. A preliminary survey of the Siluriformes. Neptune City, T. F. H. Publications, $784 \mathrm{p}$.

Burgess, W. E. 1994. The jaguar catfishes of the genus Liosomadoras. Tropical Fish Hobbyist, 1994: 88-91. 
Eigenmann, C. H. \& R. S. Eigenmann. 1890. A revision of the South American Nematognathi or Catfishes. Occasional Papers of California Academy of Sciences, 1: 1-508.

Eschmeyer, W. N. 1998. Catalog of Fishes. California Academy of Sciences, San Francisco, 697p.

Eschmeyer, W. N. \& R. Fricke. 2012. Catalog of Fishes, electronic version (30 Feb 2012). http://research.calacademy.org/research/ ichthyology/catalog/fishcatmain.asp

Ferraris Jr., C. J. 1988. The Auchenipteridae: putative monophyly and systematics, with classification of the neotropical Doradoid catfishes (Ostariophysi: Siluriformes). Unpublished Ph.D. Dissertation, City University of New York, New York, 229p.

Ferraris Jr., C. J. 2003. Family Auchenipteridae. Pp. 470-487. In: Reis, R. E., S. O. Kullander \& C. J. Ferraris Jr. (Eds.). Check list of the freshwater fishes of South and Central America. Porto Alegre, Edipucrs, 729p.

Ferraris Jr., C. J. 2007. Checklist of catfishes, recent and fossil (Osteichthyes: Siluriformes), and catalogue of siluriform primary types. Zootaxa, 1418: 1-628.

Ferraris Jr., C. J., R. P. Vari \& S. J. Raredon. 2005. Catfishes of the genus Auchenipterichthys (Osteichthyes: Siluriformes: Auchenipteridae); a revisionary study. Neotropical Ichthyology, 3: 89-106.

Finley, L. 1997. Catfish corner: the jaguar catfish. Tropical Fish Hobbyist, 1997: 104-108.

Fowler, H. W. 1940. A collection of fishes obtained by Mr. William C. Morrow in the Ucayali River Basin, Peru. Proceedings of the Academy of Natural Sciences of Philadelphia, 91: 219-289.

Gosline, W. A. 1945. Catálogo dos nematognatos de água doce da América do Sul e Central. Boletim do Museu Nacional do Rio de Janeiro, 33: 1-138.

Günther, A. 1864. Catalogue of fishes in the British Museum. Catalogue of the Physostomi, containing the families Siluridae, Characinidae, Haplochitonidae, Sternoptychidae, Scopelidae, Stomiatidae in the collection of the British Museum. British Museum Trustees, London.

Higuchi, H., J. L. O. Birindelli, L. M. Sousa \& H. A. Britski. 2007. Merodoras nheco, new genus and species of doradid from Pantanal Matogrossense, with nomination of the new subfamily Astrodoradinae (Siluriformes, Doradidae). Zootaxa, 1446: 31-42.

Lujan, N. K. \& J. L. O. Birindelli. 2011. A new distinctively banded species of Pseudolithoxus (Siluriformes: Loricariidae) from the upper Orinoco River. Zootaxa, 2941: 38-46.

Lundberg, J. G. 1998. The temporal context for the diversification of Neotropical fishes. Pp. 49-68. In: Malabarba, L. R., R. E. Reis, R. P. Vari, Z. M. Lucena \& C. A. S. Lucena (Eds.). Phylogeny and Classification of Neotropical Fishes. Porto Alegre, Edipucrs, 603p.
Lundberg, J. G. \& J. N. Baskin. 1969. The caudal skeleton of the catfishes, order Siluriformes. American Museum Novitates, 2398: 1-49.

Mees, G. F. 1974. The Auchenipteridae and Pimelodidae of Suriname (Pisces, Nematognathi). Zoologische Verhandelingen, 132: 1-256.

Mees, G. F. 1978. On the identity of Arius oncinus R. H. Schomburgk (Pisces, Nematognathi, Auchenipteridae). Zoologische Mededelingen, 52: 267-276.

Mertes, L. A., T. Dunne \& L. A. Martinelli. 1996. Channel-floodplain geomorphology along the Solimões-Amazon River, Brazil. Geological Society of America Bulletin, 108: 1089-1107.

Nijssen, H. \& I. J. H. Isbrücker. 1986. Review of the genus Corydoras from Peru and Ecuador (Pisces, Siluriformes, Callichthyidae). Studies on Neotropical Fauna and Environment, 21: 1-68.

Ready, J., E. Ferreira \& S. Kullander. 2006. Discus shes: mitochondrial DNA evidence for a phylogeographic barrier in the Amazonian genus Symphysodon (Teleostei: Cichlidae). Journal of Fish Biology, 69: 200-211.

Reis, R. E. \& T. A. K. Borges. 2006. The South American catfish genus Entomocorus (Ostariophysi: Siluriformes: Auchenipteridae), with the description of a new species from the Paraguay River basin. Copeia, 2006: 412-422.

Rössel, F. 1962. Centromochlus schultzi, ein neuer Wels aus Brasilien (Pisces, Teleostei, Auchenipteridae) [Ichthyologische Ergebnisse der Harald Schultz-Expeditionen, 3]. Senckenbergiana Biologica, 43: 27-30.

Royero, R. 1999. Studies on the systematics and phylogeny of the catfish family Auchenipteridae (Teleostei: Siluriformes). Unpublished Ph.D. Dissertation, University of Bristol, London, $534 \mathrm{p}$.

Schomburgk, R. H. 1841. The Natural History of Fishes of Guiana. Part I. Pp. 17-263. In: Jardine, W. (Ed.), The Naturalists' Library. Vol. 3. W. H. Lizars, Edinburgh.

Soares-Porto, L. M. 1998. Monophyly and interrelationships of the Centromochlinae (Siluriformes: Auchenipteridae). Pp. 331350. In: Malabarba, L. R., R. E. Reis, R. P. Vari, Z. M. S Lucena \& C. A. S. Lucena (Eds.). Phylogeny and Classification of Neotropical Fishes. Porto Alegre, Edipucrs, 603p.

Sousa, L. M. \& J. L. O. Birindelli. 2011. Taxonomic revision of the genus Scorpiodoras (Siluriformes: Doradidae) with resurrection of $S$. calderonensis and description of a new species. Copeia, 2011: 121-140.

Taylor, W. R. \& G. C. van Dyke. 1985. Revised procedures for staining and clearing small fishes and other vertebrates for bone and cartilage study. Cybium, 9: 107-119.

Weitzman, S. H. 1962. The osteology of Brycon meeki, a generalized characid fish, with an osteological definition of the family. Stanford Ichthyological Bulletin, 8: 1-77. 